This is an author produced version of a paper published in ECOLOGICAL ENGINEERING. This paper has been peer-reviewed and is proof-corrected, but does not include the journal pagination

Citation for the published paper:

Emilsson, T. (2008) Vegetation development on extensive vegetated green roofs: Influence of substrate composition, establishment method and species mix. Ecological Engineering. Volume: 33 Number: 3-4, pp 265-277.

http://dx.doi.org/10.1016/j.ecoleng.2008.05.005

Access to the published version may require journal subscription.

Published with permission from: Elsevier Bv.

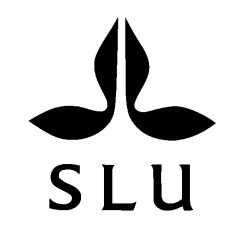

Epsilon Open Archive http://epsilon.slu.se 


\title{
Vegetation development on extensive vegetated green roofs: Influence of substrate composition, establishment method and species mix
}

\author{
Emilsson, Tobias \\ Department of Landscape management, Design and Construction \\ Faculty of Landscape Planning, Horticulture and Agricultural Science \\ Swedish University of Agricultural Sciences \\ PO Box 66 \\ SE-230 53 Alnarp \\ Sweden \\ E-mail: tobias.emilsson@1tj.slu.se \\ Telephone: +4640415154 \\ Fax number: +4640464085 \\ Published in Ecological Engineering \\ http://dx.doi.org/10.1016/j.ecoleng.2008.05.005
}




\begin{abstract}
Technology for establishment of vegetated roofs (green roofs) has developed rapidly over recent years but knowledge about how these systems will develop over time is still limited. This study investigates vegetation development on unfertilised thin extensive vegetated roofs during a 3-year period. The vegetation systems investigated were designed to be low maintenance and had a saturated weight of $50 \mathrm{~kg} / \mathrm{m}^{2}$, a thickness of $4 \mathrm{~cm}$ and drought-resistant succulent and bryophyte vegetation.
\end{abstract}

Vegetation development was investigated in relation to: establishment method, species mixture and substrate composition in a factorial experiment. Vegetation cover was investigated using point intercept.

Moss was found to develop on most substrates and reached more than $80 \%$ cover on some plots. Sedum album and Sedum acre were the dominant species on the roofs. S. acre was found to decrease drastically after two years. The lack of difference found in this study between the establishment techniques shows that there are other possible marketable ways to construct vegetated roofs in Sweden, as an alternative to vegetation mats. Uniform extensive vegetated roofs with a high dominance of succulent species have limited value for plant biodiversity, as few species establish spontaneously.

Key words: green roof, roof vegetation, sedum, substrate, establishment technique, species mix, succession, urban vegetation 


\section{Introduction}

Vegetated roofs, also known as green roofs, are constructed vegetation systems with aesthetic and environmental qualities that have become popular as an ecological roof cover. Vegetated roofs make use of otherwise unused roof surfaces; they are appreciated for their aesthetic character, their influence on urban hydrology (Bengtsson, 2005; Bengtsson et al., 2005; Villarreal \& Bengtsson, 2005), their assumed effect on energy demand for comfort cooling during summer months (Theodosiou, 2003) and their capacity to reduce urban temperatures (Lazzarin et al., 2005). Vegetated roofs can also function as important habitats for plants and animals in the urban landscape, but this generally requires a particular focus on biodiversity in the design of the vegetation system (Brenneisen, 2003).

Vegetated roofs are rather new to Sweden, with the first being installed in the early 1990s. Many of the roofs that are currently being built are extensive thin roofs, constructed according to the German roof greening tradition and the concepts and ideas developed through the Forschungsgesellschaft Landschaftsentwicklung Landschaftsbau e.V. during the last 15-20 years (FLL, 2002). These extensive vegetated roofs have substrate layers of approximately 3-5 $\mathrm{cm}$ thickness and a water-saturated weight of approximately $50 \mathrm{~kg} / \mathrm{m}^{2}$. They are aimed at retro-fitting existing flat roofs on e.g. low weight bearing industrial building roofs without the need for reconstructing the building, or as low cost roof coverings with environmental and aesthetic values on new buildings. The most common construction is a three-layered design that comprises a drainage layer, a filter layer and a vegetation layer, primarily applied as pre-grown vegetation matting. Other installation techniques such as planting, seeding or distributing cuttings on-site are more common in continental Europe due to lower price.

Substrates used on roofs in Sweden to date have primarily been based on natural soil mixes improved with scoria or lava. As most companies operating on the Swedish market have been importing technology from Germany, the substrates used are similar to those specified by German guidelines (FLL, 2002). However, there are currently no specific regulations for the design of substrates for the Swedish vegetated roof market. Substrates for vegetated roofs are designed as a constant trade-off between system weight requirements, substrate water-holding capacity and oxygen diffusion to plant roots. Long-term stability of substrates is also important and substrates have to resist decomposition and erosion through water, wind or frost (FLL, 2002). The list of suitable inorganic substrate components that can be used is long and the final selection is generally a compromise between the physical and chemical characteristics on the one hand, and material availability and price on the other (Roth-Kleyer, 2001). Recycled materials are appreciated for their reduced environmental impact with respect to extraction and production of new material and for their low price. The use of recycled materials can sometimes be problematic due to strict environmental restrictions with respect to e.g. heavy metals or nutrient content (Popp \& Fischer, 1997; Kolb et al., 2001; Roth-Kleyer, 2001; Fischer \& Jauch, 2002b). The use of recycled inorganic materials such as broken tiles or cinder and organic residues such as composted materials or sewage sludge has been very limited in Sweden compared with Germany. Two of the substrate mixes in this investigation include 
recycled broken roof tiles as a way to reduce total environmental load of the system.

Substrate water permeability, long-term stability and oxygen diffusion have in many cases been achieved by limiting the amount of organic and fine material in the substrate mix, as recommended in the German guidelines (Fll, 2002) Consequently, green roof substrates usually have low nutrient exchange capacity, as these processes take place on the surface of organic material and on the surface of fine particles (Brady \& Weil, 1999). The low nutrient exchange capacity of the substrates might affect stormwater quality, but also the long-term stability of the vegetation system if nutrients are constantly being depleted from the system.

However, most of the nutrient leaching takes place soon after installation or after fertilisation events (Emilsson et al., 2007).

The vegetation in extensive systems is almost exclusively based on plants such as Sedum spp. and Phedimus spp. or Hylotelephium spp. Most of the plants used are succulents that are able to store water in leaves or stems, which enables them to survive the dry environment. Some of the plants also exhibit crassulacean acid metabolism (CAM), which can increase the water-use efficiency of the plants by allowing stomatal opening and $\mathrm{CO}_{2}$ storage during the night, when evaporation rates are lower than during the day (Ting, 1985). The commonly used plants $S$. album, S. acre and $S$. rupestre are inducible CAM plants that switch from $\mathrm{C}_{3}$ metabolism to CAM when exposed to drought but otherwise use the more efficient $C_{3}$ pathway (Kluge, 1977; Sayed et al., 1994; Pilon-Smits et al., 1996). Herbs and grasses are frequently used elsewhere but not in Sweden, as fire restrictions prohibit the use of materials that can spread or transport fire being used as roof coverings in densely populated areas (Boverket, 2002). The vegetated roofs that are installed in Sweden are also of the thinnest type and it is questionable whether non-succulent plants would survive.

Green roofs are generally installed with limited care for the long-term development of the vegetation. The present study was therefore initiated in order to determine the importance of establishment method, substrate composition and species mix for vegetation development on unfertilised extensive vegetated roofs. To date, there are few international published studies on vegetation development on vegetated green roofs and no systematic comparisons between different substrate mixes, species mixtures and establishment techniques. Knowledge about vegetation development is important for predicting future maintenance needs and for our understanding of the role of vegetated green roofs for urban biodiversity. It is also important to know how the aesthetic qualities of extensive vegetated roofs develop over time and especially how long it takes for a surface established onsite to have the same plant cover as a prefabricated vegetation mat.

This study is a follow-up to a previous study on establishment of vegetated roofs performed in 2001 (Emilsson \& Rolf, 2005).

This study investigated the following specific issues:

- Development of roof vegetation as influenced by:

- establishment technique

- substrate design

- species mix

- Trends in the development of the roof vegetation system over time

- Development of plant biodiversity on extensive vegetated roofs 


\section{Materials and methods}

The roof plots investigated in this study were established in autumn 2000 at the

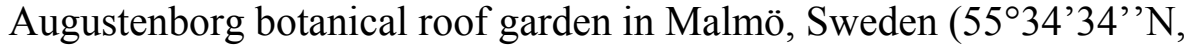
$13^{\circ} 1^{\prime} 42^{\prime}$ 'E). All plots investigated were triple-layered extensive vegetated roofs with an approximate weight of $50-55 \mathrm{~kg} / \mathrm{m}^{2}$ at full water saturation. The vegetation system was built up from a $4-\mathrm{cm}$ vegetation/substrate layer, a geotextile filter layer and a drainage mat (Aquatop) composed of recycled foam material. Each plot measured $1.15 \times 6.5 \mathrm{~m}^{2}$, had a north-westerly orientation and a $4^{\circ}$ inclination. Meteorological data for the investigation period were collected from SMHI weather station $5236\left(55^{\circ} 34^{\prime} 17^{\prime}\right.$ 'N, $13^{\circ} 4^{\prime} 24^{\prime}$ 'E), less than $3 \mathrm{~km}$ from the experiment site (Fig. 1).

All plots were given a starter fertilisation and an additional fertilisation in the spring of the following year. The fertilisers were applied as a 50:50 combination of controlled release fertiliser and conventional fertiliser (Controlled release: Multicote 8M extra 18-6-12; elemental composition (wt.\%) N:18; P: 2.58, K:10, Conventional: ProMagna 11-5-18; elemental composition (wt.\%) N:11; P: 4.6, $\mathrm{K}: 18$ ) at a rate of $15 \mathrm{~g} / \mathrm{m}^{2}$.

The roof vegetation examined in this study was established as a factorial experiment investigating three factors, substrate composition, species mix and establishment technique. Three different substrates were tested for their influence on plant cover. The first was a commercial substrate produced by the company Vegtech under the name Roofsoil (RS). This substrate is based on natural soil, lava, organic material and some other components, but the exact composition is proprietary. The second substrate, substrate A (SA), was a generic product based on crushed roof tiles and with a low organic content, and the third, Substrate B (SB), was also a generic substrate, based on crushed roof tiles and with a high organic content (Table 1a). The substrates were analysed one year after installation for physical and chemical characteristics (Table 1b; Emilsson \& Rolf, 2005). The species mix factor had three levels: A standard succulent mix (SM) normally used in production of prefabricated vegetation mats; a mix proposed for northern conditions (NM) containing a higher percentage of S. acre; and a Bigleaved mix (BLM) containing a higher proportion of deciduous species (Table 2). The establishment factor had three levels: Prefabricated vegetation mats (PV); succulent shoot establishment (SS); and a treatment involving planting of plug plants (PP).

The establishment treatment with vegetation mats (PV) was only used in combination with the commercial RS substrate, yielding an incomplete experimental design. This was handled by dividing the analysis into two parts, the first focusing on development across surfaces established on-site and the second on plant development on the commercial RS substrate (Table 3). The experiment involved 21 treatments with 5 replicates, yielding 105 plots. A full description of the experiment and substrate characteristics can be found in Emilsson \& Rolf (2005). 


\section{Vegetation survey}

The vegetation was surveyed on two occasions per year, in spring and in autumn. The spring investigation was performed when the plants had started to grow and the leaves of the deciduous plants were fully developed. The autumn investigation was carried out before the deciduous plants had started to die back for winter. The vegetation was recorded using quadrant point intercept (Greig-Smith, 1983). The grid was constructed from a 45 by $45 \mathrm{~cm}^{2}$ regular 13 x 13 grid based on two parallel nets ensuring that the vegetation was recorded perpendicularly. All vegetation that was intercepted by the projection of the cross-hairs was recorded as present. Great care was taken to record all vegetation layers by carefully moving the upper layers without disturbing the lower. In most cases, the vegetation consisted of a single layer. Vascular plant species, moss or lack of vegetation were recorded. The point-intercept measurements were complemented with a survey of plant species in every plot in order to include species with low cover. The vegetation was measured in two randomly placed fixed quadrants per experimental plot and the mean cover of the two plots was used in the calculations.

All succulents were identified and labelled according to Eggli (2003). All other vascular plants were identified and labelled according to Flora Europaea (Tutin et al., 1968-1980; Tutin, 1993)

\section{Soil and biomass analyses}

A subset of all treatments was used for the follow-up investigation of substrate nutrient content. At the start of the experiment, the two generic substrates (SA, SB) only differed in organic content, a difference that had decreased at the first investigation in 2001 (Emilsson \& Rolf, 2005). Thus as Substrate B was considered to be very similar to Substrate A, it was excluded from the analysis (Table 3). Two replicate soil samples were taken from each treatment, i.e. a total of 30 samples. Substrate samples were taken from a randomly selected 20 × 20 $\mathrm{cm}^{2}$ roof section. Plant roots and the litter layer were removed before the samples were taken to the laboratory for analysis. A randomly selected $40 \times 40 \mathrm{~cm}^{2}$ portion of the roofs was used for biomass determination. The central $10 \times 10 \mathrm{~cm}^{2}$ of this portion was used for the determination of moss biomass. The biomass was dried at $70{ }^{\circ} \mathrm{C}$ until constant weight of the samples was achieved.

Soil analysis was performed according to the methodology used for determination of chemical characteristics for green roof substrates (FLL, 2002). Organic matter content was estimated as loss on ignition $\left(550^{\circ} \mathrm{C}, 15 \mathrm{~h}\right)$. Available ammonium and nitrate were extracted from $20 \mathrm{~g}$ air-dried, sieved substrate during $60 \mathrm{~min}$ using $200 \mathrm{~mL} 0.0125 \mathrm{M} \mathrm{CaCl}_{2}$. The same extraction method was used for $\mathrm{pH}$ determination. Available phosphate and potassium were extracted from $5 \mathrm{~g}$ air-dried sieved substrate for $90 \mathrm{~min}$ using $100 \mathrm{~mL} 0.05 \mathrm{M}$ calcium acetate, $0.05 \mathrm{M}$ calcium lactate and $0.3 \mathrm{M}$ acetic acid. Total nitrogen and phosphorus were determined after Kjeldahl digestion with concentrated $\mathrm{H}_{2} \mathrm{SO}_{4}$. Detailed descriptions of methods can be found in Hoffman (1991).

Analyses of $\mathrm{NO}_{3}-\mathrm{N}, \mathrm{NH}_{4}-\mathrm{N}$, Tot- $\mathrm{N}, \mathrm{PO}_{4}-\mathrm{P}$, and Tot-P were performed using a FIA 5000 instrument from FOSS-Tecator. Nitrate nitrogen was analysed according to ISO 13395, reduced nitrogen according to ISO 11732, total nitrogen according to ISO 11905, phosphate phosphorus according to ISO 15681-1 and 
total phosphorus according to CAS 5305 (FOSS, Customer Application Summary Note). Potassium was analysed with an optical ICP AES technique using a PerkinElmer OPTIMA 3000 DV instrument. All analyses were performed in accordance with the instrument manuals.

\section{Statistical analyses}

The plant frequency cover data collected using the point intercept method were transformed using an $\arcsin \left(\mathrm{x}^{0.5}\right)$ transformation in order to obtain homogeneous variance (Underwood, 1997). However, original means are presented in graphs and tables unless otherwise stated. Development of species was investigated with ANOVA repeated measures using substrate, establishment and species mix as fixed between-subject factors. As described earlier, the analysis was split to achieve two complete experimental designs (Table 3). Lack of sphericity was corrected using Greenhouse-Geisser correction (Toutenburg, 2002). The same type of analysis was used to investigate the development of spontaneously established species. A factorial ANOVA was used to test for significant differences between the treatment combinations and the cover, biomass and nutrients at the end of the experiment. Means were separated by a Tukey test.

The significance level of the individual tests was adjusted with Bonferroni correction to correct for type I errors for the repeated statistical tests performed on cover of individual species and on substrate nutrient content (Dean, 1998). The significance level was set to $\mathrm{P}<0.05$ unless otherwise stated. All statistical analyses were performed using the SPSS vs. 12 statistical programme. 


\section{Results}

\section{Development of cover over time}

Moss cover was found to increase during the course of the experiment, reaching more than $80 \%$ cover in some treatments at the end of the experiment (Fig. 2). The moss cover on the commercial substrate (RS) remained rather constant until the autumn of 2002, after which it increased independently of treatment (Fig. 2). The moss cover on the generic substrates increased from the start of the experiment. The cover of all succulent species varied over time but the pattern was not as apparent as for the moss cover. The development of unvegetated areas on roof soil was also dependent on time. The cover decreased over time but there was no clear function that could be fitted to the data (Fig. 3).

To get an idea about why and how the vegetation is changing, it is also important to investigate the development of the individual species. The most dominant species in the species mixes were S. album and S. acre. The other succulent species had a very limited surface cover. The cover values given for these complementary species are the sum of all succulent species excluding $S$. album and S. acre. The development of $S$. album was promoted by the roof soil (RS). The development over time was found to differ between substrates and between establishment-species mix combination, but no clear function could be fitted to all the data. The surfaces that were established with Northern mix (NM) showed increasing cover of $S$. album over time but still had lower overall levels compared with the other treatments (Fig. 3). This was most apparent in the combination plug plants (PP) and Northern mix, which had lower S. album cover than all other treatments. The cover of $S$. acre was found to initially increase until the spring of 2002 and then decrease drastically over the course of the experiment (Figs. $2 \& 3$ ). The reduction was greatest for the Northern mix, which was mainly based on S. acre and had a high initial cover of this species. It was noted that the total cover of $S$. acre was lowest on prefabricated vegetation mats (PV). The cumulative cover of the complementary species excluding S. acre and S. album was generally low, being less than $15 \%$ for all treatments except for the standard mix (SM) on vegetation mats. This was mainly due to development of Phedimus spurius, which was successful on these plots (Fig. 2). Most treatments showed a marked increase in the cover of these species even if the absolute numbers were low and the variance large.

\section{Plant cover at the end of the experiment}

The first part of the analysis, excluding prefabricated vegetation mats, showed that the roof soil (RS) had a sustained advantage, with a total succulent cover of approximately $55 \%$, compared with an average cover of $30-33 \%$ on the two other substrates (SA, SB) (Table 4a). There was no difference between the establishment methods shoots (SS) or plug plants (PP) or between the species mixes in relation to succulent cover (Table 4a). The moss cover showed a contrasting pattern, with decreasing cover on roof soil (RS) substrate. The use of shoots as opposed to plug plants also positively influenced moss cover. There was no effect of species mix. The results of moss cover and the cover of the complementary succulents showed heterogeneous variance, which could not be treated by the angular transformation and thus makes the statistical tests 
unreliable. The data were still analysed with analysis of variance, as this procedure is fairly robust to departures from homogeneity of variance in balanced experiments (Underwood, 1997). However, the results should be treated with care. The experiment revealed that the amount of bare ground increased on plug planted surfaces compared with surfaces established with shoots.

The development of $S$. album and complementary succulents was positively affected by the roof soil (RS). S. album was influenced by a interaction between establishment and species mix, with the highest cover being found on plug planted (PP) plots with the standard mix (SM) or the big leaved mix (BLM), and shoot established (SS) plots with the standard mix. The lowest cover of S. album was found on surfaces plug planted with the Northern mix (NM) (Table 4a). Sedum acre cover was only affected by species mix. The high $S$. acre content of the Northern mix maintained the high cover on this treatment (Table 4a).

The second part of the analysis focused on the effect of establishment method and species mix when used on roof soil (RS). The results from the investigation revealed increased succulent cover with the standard mix and decreased cover with the big leaved mix. Moss cover showed a converse pattern. Cover of unvegetated area was dependent on an interaction between species mix and establishment technique, with the cover being highest on shoot established surfaces in combination with standard mix or big leaved mix and lowest on standard mix vegetation mats (Table $4 b$ ).

There was no difference in the S. album cover between treatments. S. acre was present in higher abundances on Northern mix established plots compared with plots established with big leaved mix. The variance for the complementary species was again found to be heterogeneous even after angular transformation. These complementary species were successful on some plots but not consistent for the treatments (Table 4b). Complementary species were most successful on vegetation mats established with the standard mix and least successful on vegetation mats established with the Northern mix.

\section{Biomass}

The plant cover in the plots was supplemented with an analysis of the standing biomass at the end of the experiment. The largest proportion of vascular plant biomass was represented by S. album, which had the highest cover on the roof soil substrate. The total biomass of succulent on plots established on-site was $124 \mathrm{~g} / \mathrm{m}^{2}$ for roof soil (RS), which was significantly higher than for the other substrates (SA, SB) (Table 5). There was no effect of either species mix or establishment technique. The biomass of $S$. acre was again promoted by the Northern mix but also by the use of succulent shoots. The largest proportion of the biomass was composed of moss species, which had a mean biomass of more than $500 \mathrm{~g} / \mathrm{m}^{2}$. There were no significant differences between the treatments on roof soil (Table $5 b)$.

\section{Chemical characteristics}

The substrate nutrient content only differed between the roof soil (RS) and the generic substrate (SA) in the plots established on-site. However, all variables were found to be different in this first analysis. In particular, the roof soil substrate had 
higher total nitrogen and phosphorous levels, potassium, available nitrate and organic content (Table 6).

The nutrient content within the roof soil (RS) part of the experiment was found to be dependent on both species mix and establishment method. The available potassium was increased by standard mix (SM), while the available phosphorous was increased in vegetation mats (PV). The $\mathrm{pH}$ was reduced in the vegetation mats. The organic content in standard mix vegetation mats was also found to be significantly higher than in all other treatments except plots plug planted (PP) with the standard mix (Table 6).

\section{Spontaneously established species}

The number of spontaneously established species differed between sampling times but showed no clear direction with respect to time for either the on-site analysis or the separate analysis of roof soil substrate (Table 7).

Species numbers were affected by the establishment method $F(1: 72)=36.894$, $\mathrm{p}<0.05$. Plots established with plug plants (PP) had on average 1.76 species per plot and were thus more likely to be colonised by more species compared with succulent shoot established (SS) surfaces, which had 1.415 species per plot. Species numbers were also increased by roof soil (RS) compared with substrate A (substrate $\mathrm{F}(2: 72)=6.664, \mathrm{p}<0.05)$, and by the big-leaved mix $(\mathrm{BLM})$ compared with Northern mix (species mix F(2:72)=4.672, $<<0.05$ ). The number of spontaneously established species was still low, with a mean total of 1.59 species per plot.

The analysis of establishment on roof soil (RS) substrate revealed a significant interaction between the species mix and establishment method (treatment $\mathrm{F}(8: 36)=21.156, \mathrm{p}<0.05)$. The highest number of species was found on vegetation mats (PV) established with the standard mix (SM), which had 2.67 species per plot. Plots established with shoots (SS) and the combination of Northern (NM) or the big-leaved (BLM) mix on vegetation mats had the least spontaneous establishment, ranging from 1.37 to 1.53 species per plot. 
There were also differences in colonisation over the season. The species colonisation of plots was not independent of season $\left(\mathrm{Chi}^{2}=112.7\right.$, d.f. $=52$, $\mathrm{p}<0.05$ ). The colonisation of plots was not as high during the autumn as during the spring. It is interesting to note that Field Maple (Acer campestre) colonised 14\% of the total number of spring plots during the experiment (Table 7). Very few of these tree individuals survived the summer months, as they were not present in as many plots in the autumn. Most of the plants are common ruderals that are often found on dry and derelict land. Some of the plants found on the roofs have their general distribution in other areas of Sweden, e.g. Poa alpina, Cerastium pumilum and perhaps Saxifraga tridactylites. 


\section{Discussion}

In Sweden, vegetated roofs are almost synonymous with the use of prefabricated vegetation mats. These systems can be delivered to a building site like any other building material and are easily installed. The vegetation mats have also been specified and described with the same format as used for building materials, making it possible and easy for building designers to specify the system (Svensk Byggtjänst, 1998; Vegtech, 2005). The effect of vegetation mats on the view of a roof is striking, as it can be transformed from grey to green in a matter of minutes or hours.

Our investigation showed that the initial advantage of using vegetation mats gradually decreases for most of the species installed. There was actually no detectable difference in the desired succulent cover or biomass between on-site establishment and vegetation mats at the end of the experiment. Thus, a building owner interested in establishing a vegetated roof with succulent vegetation can do this with any of the establishment techniques available. The actual technique chosen should depend more on the rate of greening required and the potential cost, as the final vegetation cover will be comparable. During the first year following the establishment, it was noted that birds might be a problem for plug plant establishment, as they pulled out the plugs in search for food. The plants gradually grew back even if they were at the top of the substrate and this did not seem to have any large impact on cover. However, the goal would definitely be to manufacture plug plants that are less attractive to birds by containing lower numbers of insects compared with the current practice.

Substrate design is important for the development of the vegetation. This study involved two generic substrates and one commercial substrate. The commercial substrate differed from the two generic types in every measured characteristic of the substrate already after a year. This made the comparison and the determination of the effect of different substrates difficult. The generic substrates initially differed from each other in organic matter content, a difference that was rapidly lost as the peat material supplied was decomposed. The organic material that was used in the substrate was not suited for use on a vegetated roof as it was too rapidly decomposed, and should have been replaced by a more resistant organic material. Nevertheless, substrate type was shown to have an important influence on the development of the plant cover, and the total succulent and S. album biomass.

The superior results from the use of the commercial substrate are most likely related to the higher nutrient content of this substrate, which has been shown to be beneficial to the development of succulent vegetation (Fischer \& Jauch, 2002a). The cover and the biomass almost doubled on the roof soil but there was also a significant accumulation of organic material from dead plant material during the experiment. This did not take place in the generic substrate, probably due to the lower biomass production from the succulent vegetation on these substrates. It seems as though the succulent vegetation is the driving variable for the organic substrate content, especially compared with the moss biomass, a finding that was consistent across all substrates. The results from the study are consistent with results from Getter et al. (2007) who found almost a doubling of organic material over 5 years. They also found related changes in both substrate character and 
stormwater runoff (Getter et al., 2007). The organic content of the substrate is actually connected to both the vegetation development and substrate nutrient content. Our investigation indicated that the total and dissolved nitrogen decreased more rapidly in the generic substrate compared with the roof soil substrate. Thus, the little remaining nitrogen in the generic system was gradually washed out and lost from the system. This is probably due to lower total uptake from the sparse vegetation and to lower retention rates in the highly inorganic substrate. However, the differences were not confirmed statistically and this question will have to be followed up in the future.

The natural soil component that was used in the commercial substrate was heattreated to reduce the presence of weeds and it is likely that this also reduced the presence of beneficial micro-organisms and mycorrhizal fungi, which excludes this as a possible explanation for the positive effect of roof soil on succulent biomass. The adverse effect of heat treatment on soil can be related to release of toxic substances during the heating process or to changes in physico-chemical characteristics of the substrate (Brule et al., 2001). Some AM-fungi have been shown to be killed at temperatures slightly over $50{ }^{\circ} \mathrm{C}$ (Menge et al., 1979). Sedum spp. are generally described as being non-mycorrhizal plants (Kottke, 2002) but the subject is surrounded by controversy as there are both publications and companies stating the beneficial effect of mycorrhizae on vegetation development on buildings (Busch \& Lelley, 1997).

Substrate $\mathrm{pH}$ has also been found to be highly correlated to vegetation development, a finding that emphasises the importance of incorporating material that can prevent acidification of the substrate. The constant flow of sometimes acid rain through the substrate otherwise causes a substantial reduction in substrate $\mathrm{pH}$, which in a German study fell to below 4.5 for 5 of the 23 substrates investigated, causing low plant cover (Fischer \& Jauch, 2002c). All substrates in our investigation had limestone added as a component, which probably helped in maintaining an almost neutral soil reaction through the duration of the study, even though there was a slight reduction compared with measurements one year after the establishment (Emilsson \& Rolf, 2005). The importance of stable, close to neutral substrate $\mathrm{pH}$ values for the development of similar types of vegetation is also supported by investigations on old gravel-based roofs built during the middle of the nineteenth century, which still have almost neutral values (Bornkamm, 1959; Darius \& Drepper, 1984; Bossler \& Suszka, 1998).

Most German studies have been performed on slightly thicker substrates than those used in the present study. However, the results are still comparable to those found in this study. Fischer \& Jauch (2002c) investigated 23 vegetated roofs established with Sedum spp. on $8 \mathrm{~cm}$ mineral substrate layers during a period of 9 years. Similarly to our investigation, they found decreasing substrate $\mathrm{pH}$ and increasing moss cover. Succulent cover was maintained above $80 \%$ throughout the continuation of their nine-year study in 13 of the 23 substrates investigated. The increased cover compared with our study can probably be explained by greater water storage in the 8 -cm substrate and by a yearly fertilisation with $5 \mathrm{~g}$ $\mathrm{N} / \mathrm{m}^{2}$. The total succulent plant cover in our study was not maintained above the FLL threshold of $60 \%$ for surfaces established on-site and $75 \%$ for prefabricated vegetation mats (FLL, 2002). The cover requirements in the FLL guidelines are associated with a yearly fertilisation regime of $5 \mathrm{~g} \mathrm{~N} / \mathrm{m}^{2}$, something that was not 
used in our study. Green roofs are promoted as a ecological roof covering material and it is our view that fertilisation should be kept at a minimum to prevent degradation of stormwater quality, even if fertilisation with coated fertilisers has been shown to minimise leaching (Emilsson et al., 2007). We believe that our test roofs had a satisfactory aesthetic character even though no fertilisers were used.

S. album was the dominant vascular species on the plots. This species has a fast ground-covering growth form and it has repeatedly been shown to be successful in achieving high vegetation cover on roofs (Liesecke, 1998; Schade, 2002). On the other hand, total dominance of $S$. album might make the roof less attractive and exciting, as the plants become almost entirely red when stressed. The complementary succulents constituted $20-40 \%$ of the total species mix but never achieved that proportion of the succulent cover. These species increased on some plots but not consistently depending on treatment. The reduction in cover of $S$. acre during the course of the experiment can prompt questions regarding its use in the mix, especially to such a large extent as was used in the Northern mix. S. acre was originally included in the mix as it has a more northerly distribution compared with the other succulent species but the results of our study question its applicability on vegetated roofs, at least when used in southern Sweden (Hultén, 1971). S. acre has not been regularly used in German research mixes. When used, it only had a limited contribution to cover over longer time periods (Liesecke, 1998; Schade, 2002). It was noted that $S$. acre flowered intensively during the first years of the present experiment. The dead inflorescences remained as grey patches for an extended period of time after the flowering period was ended and dieback of $S$. acre was also noted in the patches that had flowered in the previous year, but the extent was not systematically recorded. S. acre is described in the literature as being favoured by open disturbed, nutrient-rich sites, but excluded from the most fertile and highly disturbed areas (Mossberg \& Stenberg 2003; Grime et al. 2007). It is possible that the high amount of available nitrogen in the substrate in the beginning of the experiment favoured reproduction over vegetative growth, but this has to be investigated in more detail. The complementary succulent species were more successful when plug planted compared with shoot establishment but their distribution showed heterogeneous variance, making the statistical tests unreliable. The heterogeneous variance for the complementary species might be a result of the growth form of these plants and of the plantation technique. Most of the complementary species have a cushion-like growth form, creating a cover with patches of high density interspersed by barren soil or moss. The fact that the complementary species have a more radial growth pattern from a central plant compared with the ground covering characteristics of $S$. album and S. acre is probably the explanation for their increased performance in the plug plant treatment. However, the distribution of plants on the roofs was not investigated in detail in this study, something that requires greater attention in the future, particularly with respect to the visual appearance of the roofs and the possibility of combining establishment of cuttings or vegetation mats containing groundcovering species with plug plants of larger cushion-forming plants as a way to create a more attractive appearance.

The most drastic development in both cover and biomass in our study was found for moss, which increased from a cover of less than $20 \%$ in the first investigation to more than $80 \%$ in some treatments at the end of the experiment. The moss on 
the vegetated roofs also accumulated substantial amounts of biomass, reaching more than $500 \mathrm{~g} / \mathrm{m}^{2}$. The moss cover on the extensive roofs in our study is much higher, especially in such a short time span, than literature values. In most cases, moss cover does not reach more than 30-40\% during the first years (Liesecke, 1998; Buttschardt, 2001; Schade, 2002). This is probably partly due to fertilisation, which was prescribed in the German experiment. Moss is generally no problem on green roofs but digging by birds in the moss layer can have a negative effect on the aesthetic aspects and the maintenance requirements of the system. The birds spread lumps of moss, which can mar the appearance and end up in rain gutters, clogging the system. Moss cover has been shown to have both positive and negative effects on spontaneous establishment of forest tree species, with the main negative effect being associated with thick moss layers (e.g. Hanssen, 2003). Establishment of some alvar species has also been shown to be negatively affected by moss cover (Zamfir, 2000). The moss cover on our roofs was primarily dominated by Ceratodon purpureus (Nils Cronberg, unpublished data), which becomes very dry between rain events. Thus, spontaneous colonisation of these substrates by vascular plants would most likely also be reduced.

The value of an extensive vegetated roof in terms of urban biodiversity is dependent on a combination of several interacting variables. This study showed that there were few species establishing spontaneously on the vegetated roofs investigated. Some of the established species, e.g. Cerastium pumilum and Saxifraga tridactylites, had probably been brought to the site from the production facility and they were still present on the roof after 3.5 years. A different set of species were found colonising in the spring compared with in the autumn. Some of the plants found in the spring complete their life cycle during the time when there is still water available in the substrates, e.g. Erophila verna or Saxifraga tridactylites. Species such as Acer campestre did not survive the summer to any larger extent as fewer plots were colonised during the autumn and no large seedlings were ever found. Plots established with plugs showed a higher diversity, supporting the idea that seeds and plants were brought in with the plant material, as plugs are often found to contain weeds. It is unlikely that the standard uniform extensive green roofs will support a large diversity of plants, unless intentionally designed and installed for this purpose. A standard vegetated roof is established with succulent plants to create a high cover of the desired vegetation, which reduces spontaneous colonisation though competition. It is also likely that biodiversity is negatively affected by: (1) The harsh growing environment, i.e. there are only a limited number of species that can survive on these systems; (2) the lack of microtopography, i.e. there are few available niches on a flat roof; and (3) the lack of available similar biotopes with plants that have a dispersal capacity to reach the roofs (Fattorini \& Halle, 2004).

\section{Conclusions}

- The lack of difference found in this study between the establishment techniques shows that there are other possible marketable ways to construct vegetated roofs in Sweden, as an alternative to vegetation mats. The effect of establishment method on total succulent cover rapidly 
- Initial substrate nutrient content was found to be important for vegetation development but also for substrate development and its ability to maintain healthy vegetation.

- Few spontaneously established plants were found on the roofs. It is likely that extensive vegetated roofs have limited value for plant biodiversity unless they are specifically planned for this purpose with respect to microtopography, possible seed sources and substrate design.

- Unfertilised extensive vegetated roofs tend to develop into a system dominated by moss. However, the succulent vegetation still remained an important part of the plant cover for the duration of this experiment. 


\section{Acknowledgements}

This research was supported by FORMAS (Swedish Research Council for Environment, Agricultural Sciences and Spatial Planning) and a partnership between the LTJ Faculty at the Swedish University of Agricultural Sciences and the city of Malmö; their patronage is gratefully acknowledged. 


\section{References}

Bengtsson, L. 2005. Peak flows from thin sedum-moss roof. Nord Hydrol 36, 269-280.

Bengtsson, L., Grahn, L. \& Olsson, J. 2005. Hydrological function of a thin extensive green roof in southern Sweden. Nord Hydrol 36, 259-268.

Bornkamm, R. 1959. Vegetation und vegetations-entwicklung auf Kiesdächern. Vegetatio X, 1-24.

Bossler, S. \& Suszka, B. 1998. Spontanvegetation auf Dächer in Osnabrück. Das Gartenamt 37, 209-223.

Boverket 2002. Brandskydd. In Boverkets byggregler - BFS 1993:57 med ändringar till och med 2002:19. Elanders Gotab. Karlskrona.

Brady, N.C. \& Weil, R.R. 1999. The Nature and Properties of Soil. 12. ed. Prentice Hall. New Jersey

Brenneisen, S. 2003. Ökologisches Ausgleichspotenzial von Extensiven Dachbegrünungen - Bedeutung des Ersatz-Ökotops für den Arten- und Naturschutz und die Stadtentwicklungsplanung, Universität Basel. Dissertation

Brule, C., Frey-Klett, P., Pierrat, J.C., Courrier, S., Gerard, F., Lemoine, M.C., Rousselet, J.L., Sommer, G. \& Garbaye, J. 2001. Survival in the soil of the ectomycorrhizal fungus Laccaria bicolor and the effects of a mycorrhiza helper Pseudomonas fluorescens. Soil Biol Biochem 33, 1683-1694.

Busch, E. \& Lelley, J.I. 1997. Use of endomycorrhizal fungi for plant cultivation on buildings. Angew Bot 71, 50-53.

Buttschardt, T.K. 2001. Extensive Dachbegrünungen und Naturschutz, Universität Karlsruhe. Dissertation

Darius, F. \& Drepper, J. 1984. Rasendächer in West-Berlin: Ökologische Untersuchungen auf alten Berliner Kiesdächer. Das Gartenamt 33, 309315.

Dean, A. 1998. Design \& Analysis of Experiments. Springer-Verlag New York. Secaucus, NJ, USA. 763 pp.

Eggli, U. 2003. Illustrated Handbook of Succulent Plants - Crassulaceae. Springer. New York. 458 pp.

Emilsson, T., Czemiel Berndtsson, J., Mattsson, J.E. \& Rolf, K. 2007. Effect of using conventional and controlled release fertiliser on nutrient runoff from various vegetated roof systems. Ecol Eng 29, 260-271

Emilsson, T. \& Rolf, K. 2005. Comparison of establishment methods for extensive green roofs in southern Sweden. Urban For Urban Green 3, $103-$ 111.

Fattorini, M. \& Halle, S. 2004. The dynamic environmental filter model. In: Assembly Rules and Restoration Ecology : Bridging the Gap Between Theory and Practice. Temperton, V.M. (Ed.) Washington, D.C.: Island Press.

Fischer, P. \& Jauch, M. 2002a. Düngung von extensiven Dachbegrünungen. Dach + Grün 11, 22-28.

Fischer, P. \& Jauch, M. 2002b. Kompost in Substraten zur Dachbegrünung. Dach + Grün 11, 14-19. 
Fischer, P. \& Jauch, M. 2002c. Substrate für einschichtige Extensivbegrünungen Langzeitbeobachtungen. Dach + Grün 11, 19-23.

FLL. 2002. Richtlinie für die Planung, Ausführung und Pflege von

Dachbegrünungen. Forschungsgesellschaft Landschaftsentwicklung Landschaftsbau E.V. Bonn. 95 pp.

Getter, K.L., Rowe, D.B. \& Andresen, J.A. 2007. Quantifying the effect of slope on extensive green roof stormwater retention. Ecological Engineering 31, 225-231.

Greig-Smith, P. 1983. Quantitative Plant Ecology. 3 3. Blackwell Scientific Publications. Oxford. 359 pp.

Grime, J. P., Hodgson, J.G. \& Hunt, R. 2007. Comparative Plant Ecology: A Functional Approach to Common British Species. Colvend: Castlepoint Press.

Hanssen, K.H. 2003. Natural regeneration of Picea abies on small clear-cuts in SE Norway. Forest Ecol Manag 180, 199-213.

Hoffmann, G. 1991. Die Untersuchung von Böden - Methodenbuch 1. VDLUFAVerlag. Darmstadt.

Hultén, E. 1971. Atlas över växternas utbredning i Norden. 2nd ed. Generalstabens litografiska anstalts förlag. Stockholm. $531 \mathrm{pp}$.

Kluge, M. 1977. Is Sedum acre L. a CAM plant? Oecologia 29, 77-83.

Kolb, W., Trunk, R. \& Eppel, J. 2001. Recyclingbaustoffe zur Dachbegrünung. Deutscher Gartenbau, 32-35.

Kottke, I. 2002. Mycorrhizae - rhizosphere determinants of plant communities. In: Plant Roots: The Hidden Half. Edited by Y. Waisel. Marcel Dekker Incorporated. New York, NY, USA. 944 pp.

Lazzarin, R.M., Castellotti, F. \& Busato, F. 2005. Experimental measurements and numerical modelling of a green roof. Energ Buildings 37, 1260-1267.

Liesecke, H.-J. 1998. Langzeitentwicklung einer extensiven Dachbegrünung. Untersuchungen zum Substratverhalten und zur Vegetationsentwicklung eines 1985 ausgeführten Objektes. Stadt-und-Grün 47, 428-436.

Menge, J.A., Johnson, E.L.V. \& Minassian, V. 1979. Effect of heat treatment and three pesticides upon the growth and reproduction of the mycorrhizal fungus Glomus fasciculatus. New Phytol 82, 473-480.

Mossberg, B. \& Stenberg, L. 2003. Den nya nordiska floran. Stockholm: Wahlström \& Widstrand

Pilon-Smits, E.A.H., t' Hart, H. \& Van Brederode, J. 1996. Evolutionary aspects of crassulacean acid metabolism in the Crassulaceae. In: Crassulacean Acid Metabolism: Biochemistry, Ecophysiology, and Evolution. Edited by J.A.C. Smith. Berlin : Springer-Vlg. Berlin. 349-359 pp.

Popp, L. \& Fischer, P. 1997. Bioabfallkompost in dachsubstraten. Deutscher Gartenbau 51, 1788-1791.

Roth-Kleyer, S. 2001. Vegetationstechnische Eigenschaften mineralischer Substratkomponenten zur Herstellung von Vegetationstrag- und Dränschichten für bodenferne Begrünungen. Dach + Grün 10, 4-11.

Sayed, O.H., Earnshaw, M.J. \& Cooper, M. 1994. Growth, water relations, and CAM induction in Sedum album in response to water stress. Biol Plantarum Prague 36, 383-388. 
Schade, C. 2002. Eigenschaften und Anwendung von Vegetationsmatten in der extensiven Dachbegrünung, Universität Hannover.

Svensk Byggtjänst 1998. Hus AMA 98. Norstedt. Stockholm. 747 pp.

Theodosiou, T.G. 2003. Summer period analysis of the performance of a planted roof as a passive cooling technique. Energ Buildings 35, 909-917.

Ting, I.P. 1985. Crassulacean acid metabolism. Annu Rev Plant Physio 36, 595622.

Toutenburg, H. 2002. Statistical Analysis of Designed Experiments. SpringerVerlag New York. Secaucus, NJ, USA. 325 pp.

Tutin, T.G. (Ed.) 1993. Flora Europaea. $2^{\text {nd }}$ ed. Cambridge Univ. Press. Cambridge.

Tutin, T.G., Heywood, V.H., Burges, N.A., Moore, D.M., Valentine, D.H., Walters, S.M. \& Webb, D.A. 1968-1980. Flora Europaea. Cambridge University Press. Cambridge.

Underwood, A.J. 1997. Experiments in Ecology: Their Logical Design And Interpretation Using Analysis of Variance. Cambridge Univ. Press. Cambridge. 504 pp.

Vegtech 2005. Förslag till AMA-text: Moss-sedum taklutning 0-2 grader. Vegtech AB. http://www.vegtech.se/AMA-texter/AMAkod\%20XMS\%200-2\%20Prefab.pdf (accessed: 20060320).

Villarreal, E.L. \& Bengtsson, L. 2005. Response of a Sedum green-roof to individual rain events. Ecol Eng 25, 1-7.

Zamfir, M. 2000. Effects of bryophytes and lichens on seedling emergence of alvar plants: Evidence from greenhouse experiments. Oikos 88, 603-611. 
Table 1. Substrate a) components and b) chemical and physical characteristics one year after establishment for the three substrates: Roof soil, substrate A and substrate B 
a)

\begin{tabular}{llll}
\hline Component & $\begin{array}{l}\text { Roof soil (RS) } \\
(\text { wt. \%) }\end{array}$ & $\begin{array}{l}\text { Substrate A (SA) } \\
\text { (wt. \%) }\end{array}$ & $\begin{array}{l}\text { Substrate B (SB) } \\
\text { (wt. \%) }\end{array}$ \\
\hline Clay & $*$ & 5 & 5 \\
Broken limestone 8-12 mm & $*$ & 5 & 5 \\
Crushed roof tiles 8-12 mm & $*$ & 50 & 43 \\
Sand & $*$ & 37 & 37 \\
Organic material (Peat) & $*$ & 3 & 10 \\
\hline
\end{tabular}

* The content of the Roof soil substrate was proprietary

b)

\begin{tabular}{lllll}
\hline Measurement: & & Roof soil (RS) & Substrate A (SA) & Substrate B (SB) \\
\hline Density (dry) & $\mathrm{g} / \mathrm{cm}^{3}$ & 1.37 & 1.47 & 1.48 \\
Total pore space & $\%$ & 46.67 & 44.01 & 43.34 \\
Maximum WHC & $\%$ & 45.14 & 34.98 & 40.00 \\
(Fll, 2002) & $\%$ & 5.25 & 1.02 & 1.60 \\
Organic content & $\%$ & 7.35 & 7.49 & 7.49 \\
$\mathrm{pH}$ & & 4.35 & 0.62 & 0.66 \\
$\mathrm{Ca}$ & $(\mathrm{g} / 100 \mathrm{~g})$ & 1.48 & 1.25 \\
$\mathrm{P}$ & $(\mathrm{mg} / 100 \mathrm{~g})$ & 1.74 & 4.15 & 5.25 \\
$\mathrm{~K}$ & $(\mathrm{mg} / 100 \mathrm{~g})$ & 12.45 & 1.03 & 2.00 \\
$\mathrm{Mg}$ & $(\mathrm{mg} / 100 \mathrm{~g})$ & 2.77 & 1.62 & 1.51 \\
$\mathrm{~N}$ mineral & $(\mathrm{mg} / 100 \mathrm{~g})$ & 1.78 & 68.57 & 67.43 \\
$\mathrm{~N}$ total & $(\mathrm{mg} / 100 \mathrm{~g})$ & 219.27 &
\end{tabular}

Measurements adopted from Emilsson and Rolf (2005). 
Table 2. Composition (\%) of the three species mixes (standard (SM), Northern (NM) and big-leaved mix (BLM)) used in the establishment 


\begin{tabular}{|c|c|c|c|}
\hline Species & SM & NM & BLM \\
\hline Sedum acre (L.) & 40 & 70 & 30 \\
\hline Sedum album (L.) & 40 & 10 & 30 \\
\hline Sedum rupestre (L.) & & & 5 \\
\hline Sedum sexangulare (L.) & 5 & & 10 \\
\hline Hylotelephium ewersii (Ledebour) & 5 & 5 & \\
\hline $\begin{array}{l}\text { Phedimus floriferus 'Weihenstephaner Gold' } \\
\text { (Praeger) }\end{array}$ & & & 10 \\
\hline Phedimus hybridus (L.) & & 5 & \\
\hline Phedimus kamtschaticus (Fischer \& C.A. Meyer) & & & 5 \\
\hline Phedimus spurius (M. von Bieberstein) & 10 & 10 & 10 \\
\hline
\end{tabular}


Table 3. Experimental setup for investigating the impact of substrate (RS, SA, $\mathrm{SB}$ ), species composition (SM, NM, BLM) and establishment (PV, SS, PP) on vegetation development. The first part of the analysis was performed on treatments inside shaded boxes and the second on the treatments in italics. The investigation of plant cover and species numbers involved all treatments. The analysis of substrate nutrient content excluded Substrate B (SB) 
Substrate

\begin{tabular}{llll} 
Species mix & RS & SA & SB \\
\hline \multirow{3}{*}{ SM } & $P V$ & - & - \\
& $P P$ & PP & PP \\
& $S S$ & SS & SS \\
\hline \multirow{3}{*}{ NM } & $P V$ & - & - \\
& $P P$ & PP & PP \\
& $S S$ & SS & SS \\
\hline \multirow{3}{*}{ BLM } & $P V$ & - & - \\
& $P P$ & PP & PP \\
& $S S$ & SS & SS \\
\hline
\end{tabular}


Table 4. Cover of succulents, moss and unvegetated areas on 3.5-year-old vegetated roofs: a) established on-site and b) using roof soil (RS). Comp. succ. denotes the cover of all succulent species except $S$. album and S. acre. Treatments were analysed with Anova and differences separated using Tukey, $p<0.05$. The total significance level for the two analyses was set to $p<0.05$ with individual tests adjusted for multiple comparisons using Bonferroni adjustment. Values within rows and factor with different superscripts are significantly different 
a)

\begin{tabular}{|c|c|c|c|c|c|c|c|c|}
\hline & \multicolumn{3}{|c|}{ Substrate } & \multicolumn{2}{|c|}{ Est. method } & \multicolumn{3}{|c|}{ Species composition } \\
\hline & $\mathrm{RS}$ & SA & SB & PP & SS & SM & NM & BLM \\
\hline$\overline{\text { S. acre }}$ & 0.103 & 0.086 & 0.091 & 0.087 & 0.1 & $0.065^{\mathrm{b}}$ & $0.16^{\mathrm{a}}$ & $0.055^{\mathrm{b}}$ \\
\hline Comp. succ. & $0.041^{\mathrm{a}}$ & $0.009^{\mathrm{b}}$ & $0.013^{\mathrm{b}}$ & $0.032^{\mathrm{a}}$ & $0.01^{\mathrm{b}}$ & 0.012 & 0.025 & 0.026 \\
\hline Moss & $0.578^{\mathrm{b}}$ & $0.796^{\mathrm{a}}$ & $0.777^{\mathrm{a}}$ & $0.673^{\mathrm{b}}$ & $0.761^{\mathrm{a}}$ & 0.704 & 0.72 & 0.727 \\
\hline Succulent & $0.555^{\mathrm{a}}$ & $0.299^{b}$ & $0.334^{\mathrm{b}}$ & 0.403 & 0.389 & 0.428 & 0.385 & 0.375 \\
\hline Unveg. area & 0.093 & 0.103 & 0.103 & $0.112^{\mathrm{a}}$ & $0.088^{\mathrm{b}}$ & 0.087 & 0.101 & 0.111 \\
\hline
\end{tabular}

Substrate Est. method x species

RS SA SB PPxSM PPxNM PPxBLM SSxSM SSxNM SSxBLM

\begin{tabular}{|c|c|c|c|}
\hline S. album & $0.427^{\mathrm{a}} 0.207^{\mathrm{b}} 0.233^{\mathrm{b}}$ & $0.405^{\mathrm{a}}$ & $0.164^{b}$ \\
\hline
\end{tabular}


b)

\begin{tabular}{llllllll}
\hline & \multicolumn{3}{l}{ Est. method } & & \multicolumn{3}{l}{ Species mix } \\
\cline { 2 - 3 } \cline { 7 - 8 } & PP & SS & PV & & SM & NM & BLM \\
\hline S. album & 0.429 & 0.424 & 0.397 & & 0.479 & 0.396 & 0.374 \\
S. acre & 0.092 & 0.115 & 0.061 & & $0.077^{\mathrm{ab}}$ & $0.142^{\mathrm{a}}$ & $0.049^{\mathrm{b}}$ \\
Moss & 0.489 & 0.667 & 0.492 & & $0.420^{\mathrm{b}}$ & $0.580^{\mathrm{ab}}$ & $0.648^{\mathrm{a}}$ \\
Succulent & 0.561 & 0.549 & 0.543 & & $0.63^{\mathrm{a}}$ & $0.553^{\mathrm{ab}}$ & $0.47^{\mathrm{b}}$ \\
\hline
\end{tabular}

Est. Method x Species mix

PPxSM PPxNM PPxBLM SSxSM SSxNM SSxBLM PVxSM PVxNM PVxBLM

Comp. succ. $0.0443^{\mathrm{ab}} 0.0568^{\mathrm{ab}} 0.0578^{\mathrm{ab}} \quad 0.0136^{\mathrm{ab}} 0.0378^{\mathrm{ab}} 0.0325^{\mathrm{ab}} \quad 0.227^{\mathrm{a}} \quad 0.00118^{\mathrm{c}} 0.0722^{\mathrm{b}}$

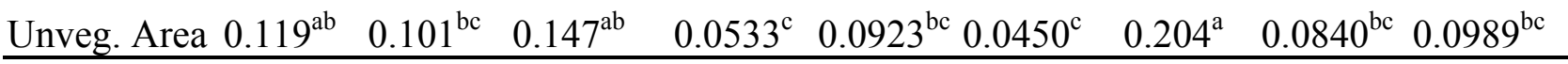


Table 5. Biomass (DW g/ $\mathrm{m}^{2}$ ) of succulent species and moss on 3.5-year-old vegetated roofs: a) established on-site and b) using roof soil (RS). Comp. succ. denotes the cover of all succulent species except $S$. album and S. acre. Treatments were analysed with Anova and differences separated using Tukey, $p<0.05$. The total significance level for the two analyses was set to $p<0.05$ with individual tests adjusted for multiple comparisons using Bonferroni adjustment. Values within rows and factor with different superscripts are significantly different 
a)

\begin{tabular}{|c|c|c|c|c|c|c|c|c|}
\hline \multirow{2}{*}{$\begin{array}{l}\text { Biomass } \\
\left(\mathrm{DW} \mathrm{g} / \mathrm{m}^{2}\right)\end{array}$} & \multicolumn{3}{|c|}{ Substrate } & \multicolumn{2}{|c|}{ Establishment } & \multicolumn{3}{|c|}{ Species mix } \\
\hline & $\mathrm{RS}$ & $\mathrm{SA}$ & SB & $\mathrm{PP}$ & SS & $\mathrm{SM}$ & NM & BLM \\
\hline S. acre & 21.01 & 14.56 & 14.25 & $11.66^{\mathrm{b}}$ & $21.55^{\mathrm{a}}$ & $11.83^{b}$ & $25.83^{\mathrm{a}}$ & $12.16^{\mathrm{b}}$ \\
\hline S. album & $89.78^{a}$ & $41.94^{b}$ & $42.94^{\mathrm{b}}$ & 59.67 & 56.76 & 48.81 & 42.13 & 83.73 \\
\hline Succulent & $124.1^{\mathrm{a}}$ & $62.25^{\mathrm{b}}$ & $64.45^{\mathrm{b}}$ & 86.44 & 80.75 & 65.3 & 80.78 & 104.6 \\
\hline Moss & 533.2 & 656.4 & 580.9 & 625.7 & 554.6 & 641.2 & 610.1 & 519.2 \\
\hline Comp. succ. & 13.29 & 5.747 & 7.26 & 15.1 & 2.43 & 4.67 & 12.82 & 8.81 \\
\hline
\end{tabular}


b)

\begin{tabular}{|c|c|c|c|c|c|c|}
\hline \multirow{2}{*}{$\begin{array}{l}\text { Biomass } \\
\left(\text { DW g*m }{ }^{-2}\right)\end{array}$} & \multicolumn{3}{|c|}{ Establishment } & \multicolumn{3}{|c|}{ Species mix } \\
\hline & $\mathrm{PP}$ & SS & $\mathrm{PV}$ & SM & NM & BLM \\
\hline S. acre & 12.97 & 29.05 & 11.17 & 16.39 & 24.03 & 12.77 \\
\hline S. album & 103.13 & 76.43 & 51.06 & 68.28 & 70.82 & 91.51 \\
\hline Succulent & 136.4 & 111.8 & 132.6 & 127.8 & 110.3 & 142.7 \\
\hline Moss & 561.8 & 504.6 & 419.3 & 393 & 571.4 & 521.2 \\
\hline Comp. succ. & 20.28 & 6.31 & 70.35 & 43.09 & 15.47 & 38.37 \\
\hline
\end{tabular}


Table 6. Substrate nutrient content on 3.5-year-old vegetated roofs: a) established on-site and b) using roof soil (RS). Treatments were analysed with Anova and differences separated using Tukey, $p<0.05$. The total significance level for the two analyses was set to $p<0.05$ with individual tests adjusted for multiple comparison using Bonferroni adjustment. Values within rows and factor with different superscripts are significantly different 
a)

\begin{tabular}{|c|c|c|c|c|c|c|c|}
\hline & \multicolumn{3}{|c|}{$\underline{\text { Species mix }}$} & \multicolumn{2}{|c|}{ Establishment } & \multicolumn{2}{|l|}{ Substrate } \\
\hline & SM & NM & BLM & $\mathrm{PP}$ & SS & $\mathrm{RS}$ & SA \\
\hline (mg/100g dry soil) & 9.36 & 8.88 & 8.36 & 8.83 & 8.91 & $12.302^{\mathrm{a}}$ & $5.437^{\mathrm{b}}$ \\
\hline (mg/100g dry soil) & 2.32 & 2.15 & 1.73 & 2.25 & 1.88 & $2.964^{\mathrm{a}}$ & $1.165^{b}$ \\
\hline N-min (mg/100g dry soil) & 0.52 & 0.41 & 0.35 & 0.40 & 0.46 & $0.619^{\mathrm{a}}$ & $0.234^{\mathrm{b}}$ \\
\hline $\mathrm{NH}_{4}-\mathrm{N}(\mathrm{mg} / 100 \mathrm{~g}$ dry soil $)$ & 0.34 & 0.22 & 0.19 & 0.25 & 0.25 & $0.358^{\mathrm{a}}$ & $0.139^{\mathrm{b}}$ \\
\hline $\mathrm{NO}_{3}-\mathrm{N}(\mathrm{mg} / 100 \mathrm{~g}$ dry soil $)$ & 0.18 & 0.19 & 0.16 & 0.14 & 0.21 & $0.261^{\mathrm{a}}$ & $0.0944^{\mathrm{b}}$ \\
\hline Tot-N (mg/100g dry soil) & 119.18 & 114.79 & 111.59 & 116.17 & 114.21 & $201.394^{\mathrm{a}}$ & $28.981^{\mathrm{b}}$ \\
\hline Tot-P (mg/100g dry soil) & 79.16 & 74.34 & 74.88 & 75.19 & 77.06 & $105.879^{\mathrm{a}}$ & $46.374^{\mathrm{b}}$ \\
\hline $\mathrm{pH}$ & 6.95 & 6.94 & 6.95 & 6.97 & 6.93 & $7.115^{\mathrm{a}}$ & $6.776^{\mathrm{b}}$ \\
\hline Org. & 5.06 & 4.77 & 4.79 & 4.87 & 4.88 & $8.300^{\mathrm{a}}$ & $1.452^{\mathrm{b}}$ \\
\hline
\end{tabular}


b)

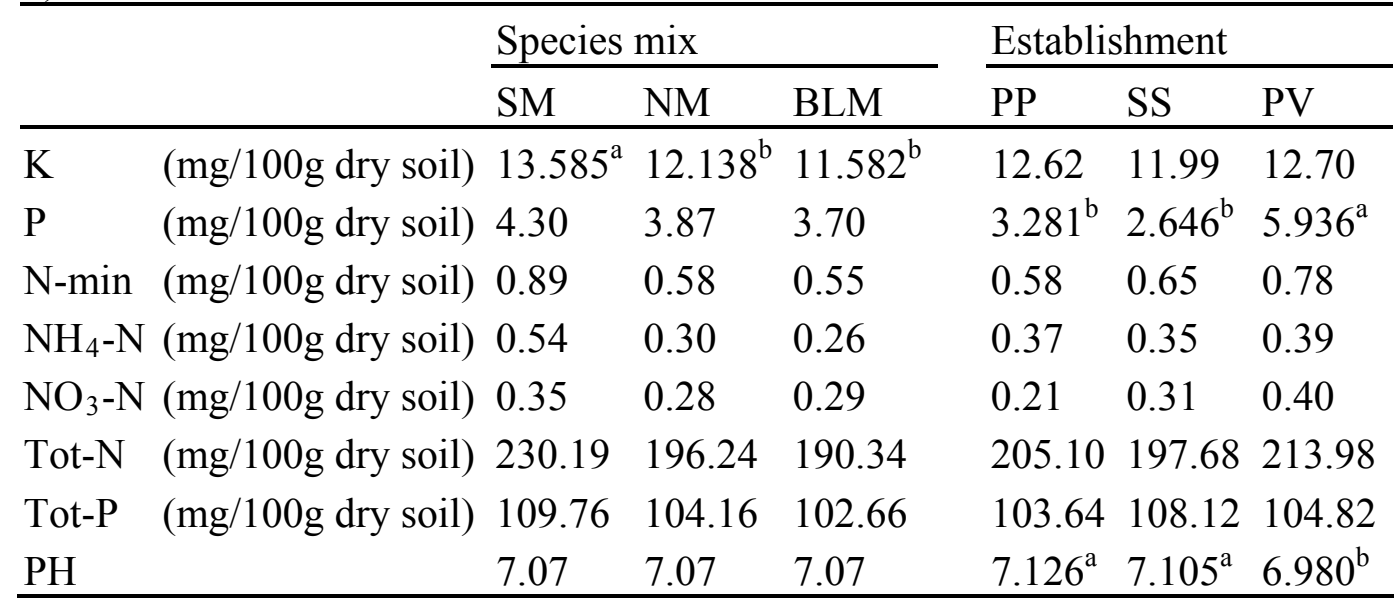

Est. Method x Species mix

PPxSM PPxNM PPxBLMSSxSM SSxNM SSxBLM PVxSM PVxNM PVxBLM

\begin{tabular}{|c|c|c|c|c|c|}
\hline Org. $\% 9.184^{\mathrm{ab}}$ & $7.852^{b}$ & $8.000^{\mathrm{b}}$ & $8.268^{b}$ & $8.227^{b}$ & $8.268^{b}$ \\
\hline
\end{tabular}


Table 7. Spontaneously established species over the 3.5-year experiment. Data are separated by season (spring, autumn) and show the percentage of total number of plots colonised 


\begin{tabular}{llll}
\hline Spring & $\%$ & Autumn & $\%$ \\
\hline Erophila verna & 18.7 & Cerastium semidecandrum & 3.2 \\
Acer campestre & 14.3 & Poa alpina & 2.5 \\
Cerastium semidecandrum & 11.4 & Cerastium pumilum & 1.9 \\
Saxifraga tridactylites & 9.5 & Arabidopsis thaliana & 1.6 \\
Cerastium pumilum & 2.5 & Senecio vulgaris & 1.6 \\
Arenaria serpyllifolia & 2.2 & Acer campestre & 1.3 \\
Poa pratensis & 2.2 & Poa annua & 1.3 \\
Cerastium glomeratum & 1.9 & Cerastium fontanum & 1.0 \\
Senecio vulgaris & 1.9 & Taraxacum & 1.0 \\
Poa alpine & 1.6 & Crepis tectorum & 0.6 \\
Cerastium fontanum & 1.3 & Epilobium sp. & 0.6 \\
Poa sp. & 1.0 & Hieracium pilosella & 0.6 \\
Antennaria dioica & 0.6 & Agrostis vinealis & 0.3 \\
Epilobium sp. & 0.6 & Cerastium glomeratum & 0.3 \\
Stellaria media & 0.6 & Erophila verna & 0.3 \\
Taraxacum & 0.6 & Poa pratensis & 0.3 \\
Betula sp. & 0.3 & Saxifraga granulata & 0.3 \\
Crepis tectorum & 0.3 & Saxifraga tridactylites & 0.3 \\
Rumex acetosella & 0.3 & & \\
Senecio vernalis & 0.3 & & \\
Veronica arvensis & 0.3 & &
\end{tabular}


Fig. 1. Daily air temperature and precipitation from autumn 2000 until spring 2004. Meteorological data were collected from SMHI automated weather station $5235\left(55^{\circ} 34^{\prime} 17^{\prime}\right.$ 'N, $13^{\circ} 4^{\prime} 24^{\prime}$ 'E). Average annual rainfall during the period was $946 \mathrm{~mm}$. 

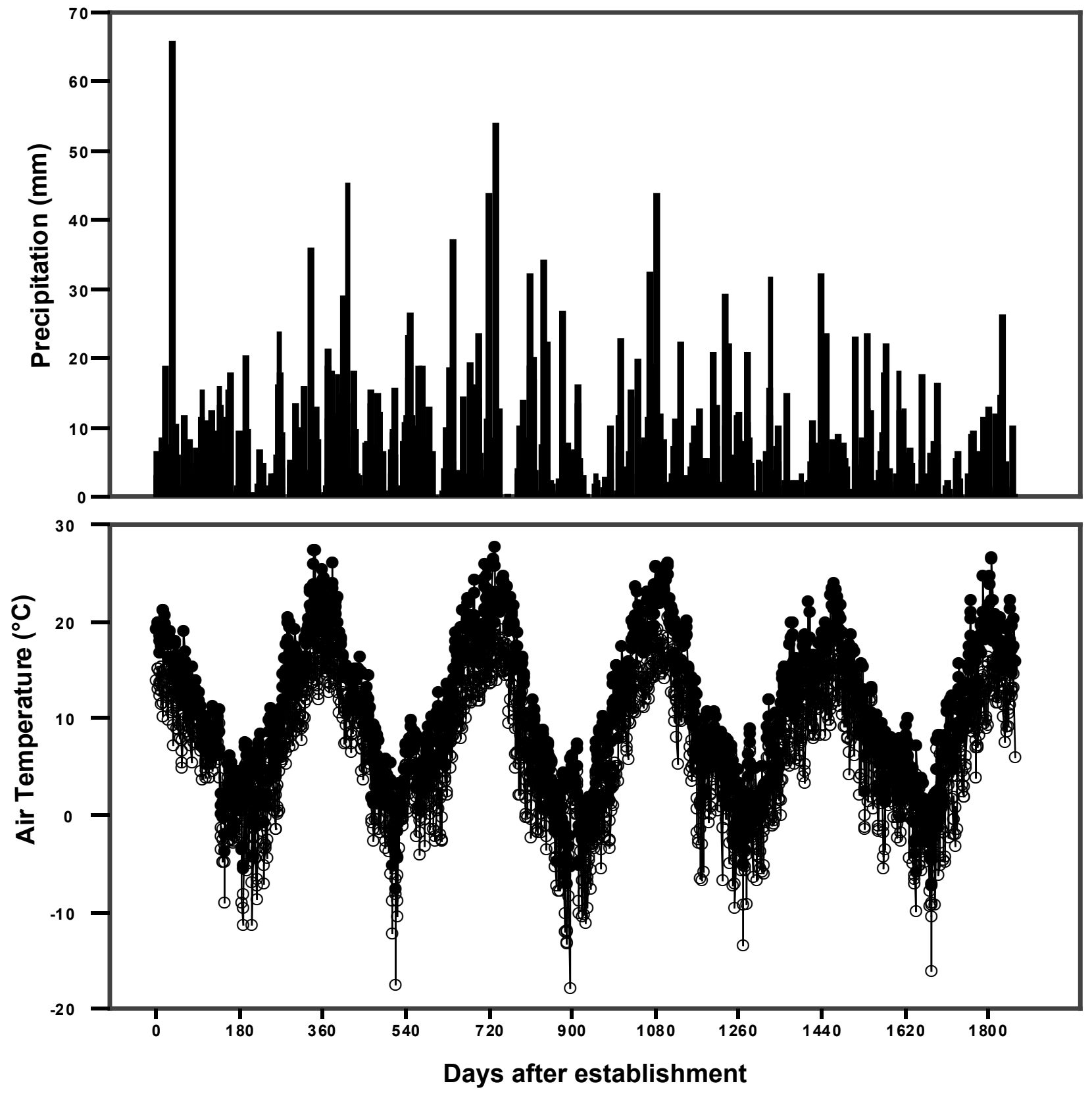
Fig. 2. Three-year development of cover on plots established on-site. Succulent $=$ cover of all succulent species used, Comp. succ. $=$ cover of complementary succulent plants, i.e. succulent cover except S. album and S. acre. Note difference in scale for Comp. succ. Filled circles = roof soil (RS), open boxes = substrate A $(\mathrm{SA})$, open triangles $=$ substrate $\mathrm{B}(\mathrm{SB})$. The $\mathrm{x}$-axis shows age of vegetation system and season (F: fall; $\mathrm{S}$ : spring). 


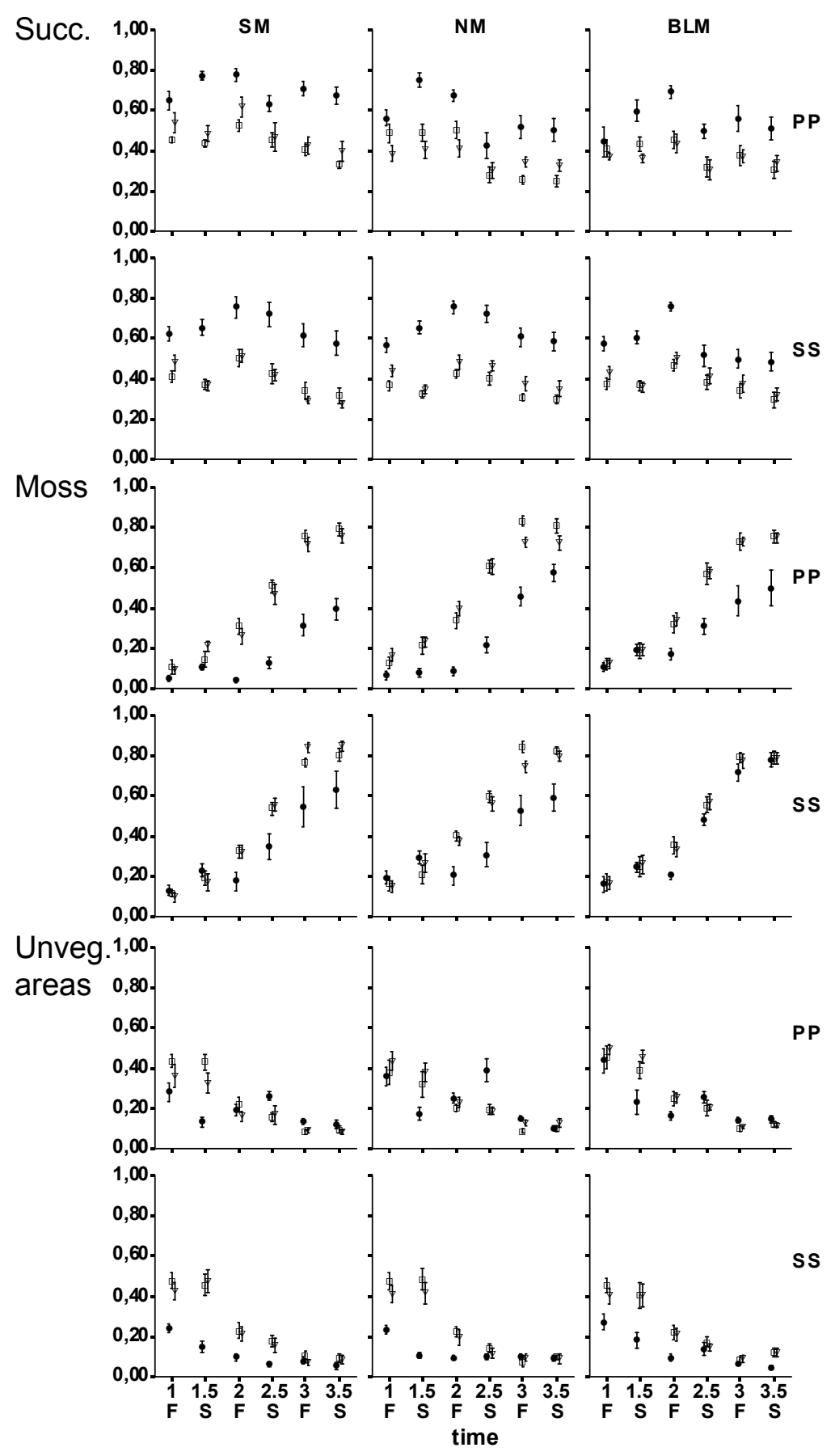


S. acre

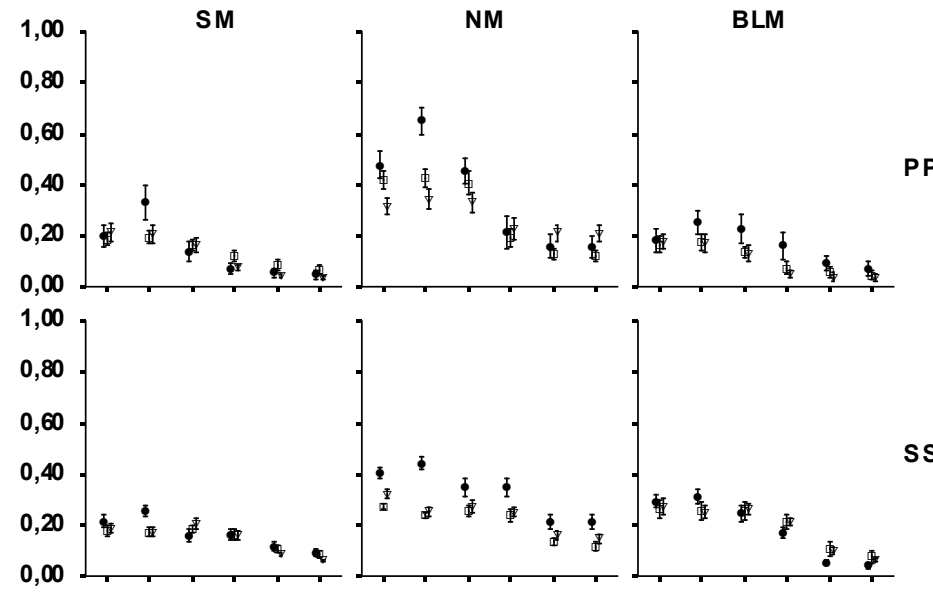

S. album
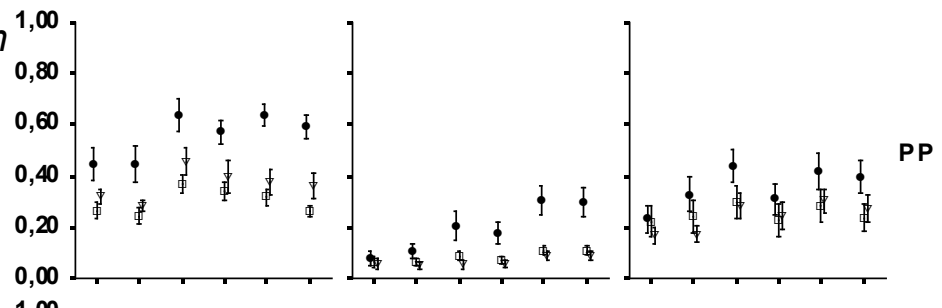

Comp. $\quad 0,10$. succ. $\quad 0,08$. 0,06 . 0,04 0,02
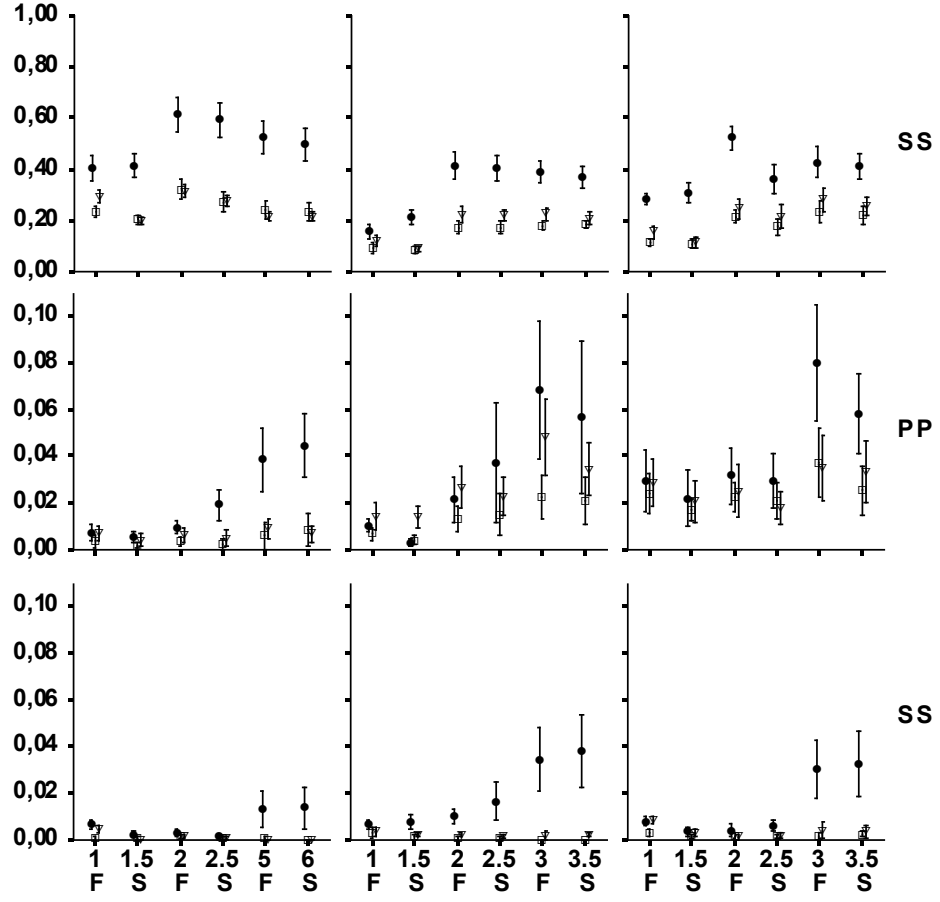
time 
Fig 3. Three-year development of cover on roof soil (RS) substrate. Succulent $=$ cover of all succulent species used, Comp. succ. $=$ cover of complementary succulent plants, i.e. succulent cover except S. album and S. acre. Note difference in scale for Comp. succ. Filled circles = plug plants (PP), open boxes = succulent shoots (SS), open triangles - vegetation mats (PV). The x-axis shows age of vegetation system and season (F: fall; $\mathrm{S}$ : spring). 
Succ. $\left.\left.\quad{ }^{1,00}\right] \quad{ }_{\mathrm{T}}^{\text {SM }}\right] \quad$ NM $]$ BLM

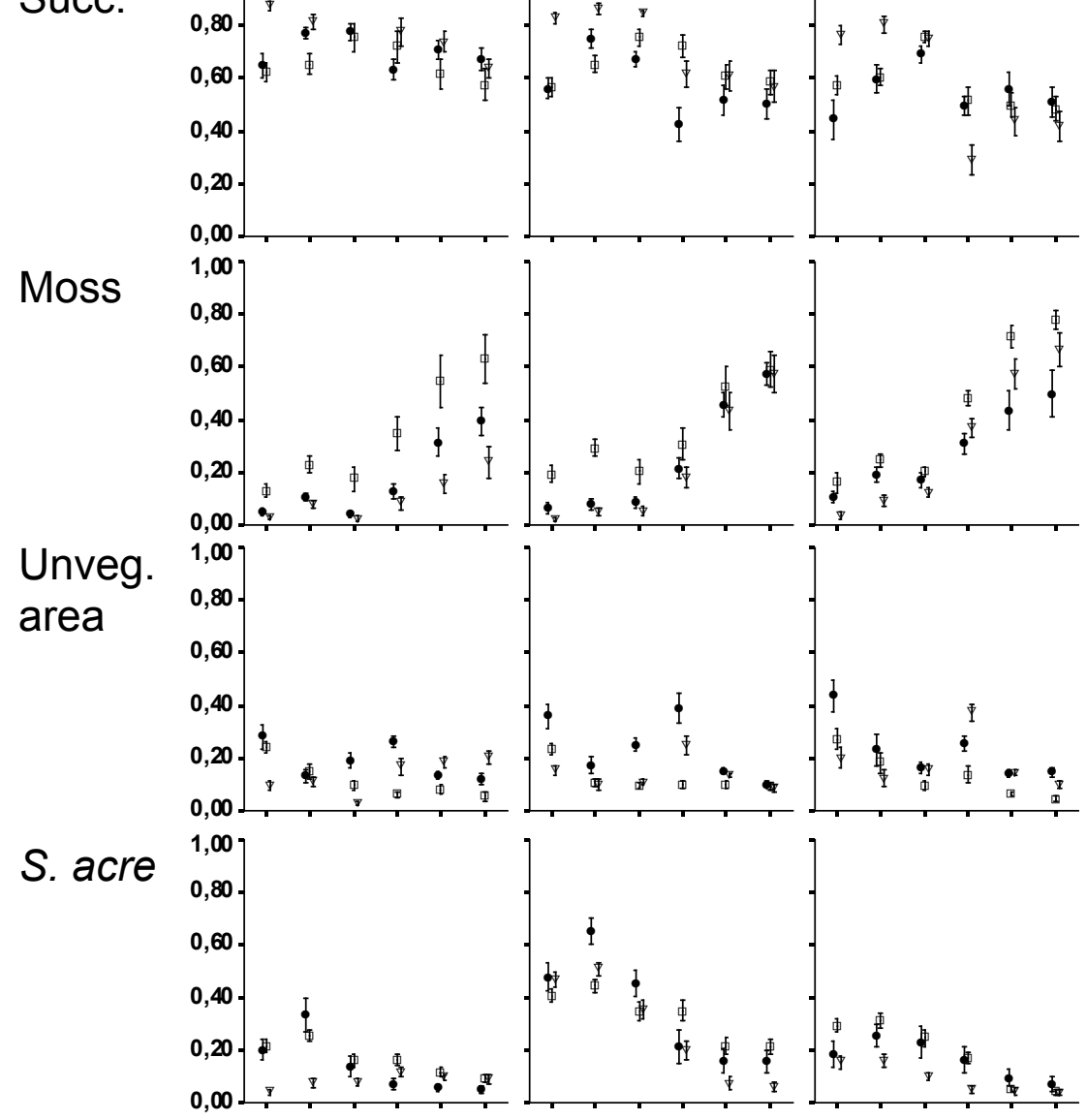

S. album

Comp.
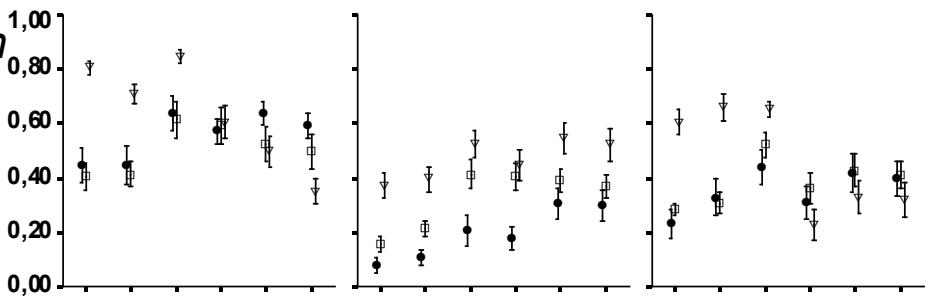

succ.
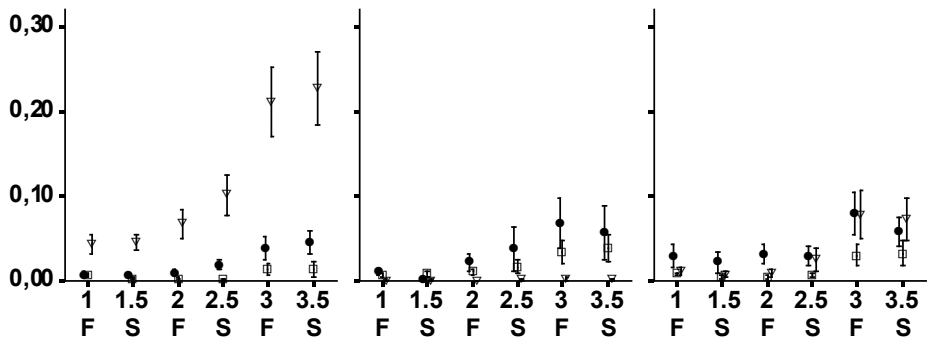